\title{
Computer Modeling of Water Supply and Sewerage Networks as a Tool in an Integrated Water and Wastewater Management System in Municipal Enterprises
}

\author{
Wojciech Kruszyński ${ }^{1 *}$, Jacek Dawidowicz' \\ 1 Bialystok University of Technology, Faculty of Civil and Environmental Engineering, ul. Wiejska 45a, 15-351, \\ Białystok, Poland \\ * Corresponding author's e-mail: w.kruszynski@pb.edu.pl
}

\begin{abstract}
The purpose of the study was to present the principles of creating and implementing an integrated water and wastewater management system based on hydrodynamic modeling of water distribution and sewage disposal systems in small and medium-sized municipal enterprises. The computer modeling of water and sewerage networks is an efficient tool for finding the causes of increased costs of operation of these plants. The simulations carried out in modeling programs enable to quickly find the optimal variant to solve the problem of exploitation or economically effective direction of their modernization. Geospatial data (GIS) is being increasingly often being used to optimally manage the municipial water and sewage infrastructure. This gives an additional analytical tool for planning, designing, obtaining operational data, etc. The integration of hydraulic models of the water supply and living and economic networks into one coherent management system is possible, owing to which, a holistic assessment of the functioning of the water and sewage management system in the city is possible. The decision support systems based on the spatial information system (GIS) associated with various specialized software, are becoming the standard of modern management of a water and sewage company. To date, only about $40 \%$ of enterprises in this industry in Poland have used systems of this type. In addition, most of the GIS-based management systems used in practice are limited to an inventory of existing network resources and integration of many databases in one coherent IT system. Only in a few cases, the systems of this type contain modules modeling the network operation under dynamic conditions, which results primarily from the additional implementation costs related to the construction of sufficiently reliable models of the water supply and / or sewerage network. Implementation of the proposed solution includes: construction of a water supply network simulation system, construction of a domestic and economic sewage system simulation system, devising scenarios for system operation under the conditions of city development and climate change, multi-criteria assessment of the economic effectiveness of systems operation taking into account social and environmental criteria, development of an integrated management system the system, taking into account the guidelines for increasing the effectiveness of its operation and work safety.
\end{abstract}

Keywords: computer modeling of water supply and sewerage networks, GIS

\section{INTRODUCTION}

Geospatial data (GIS) is being increasingly often used to optimally manage the municipial water and sewage infrastructure. This gives an additional analytical tool for planning, designing, obtaining operational data, etc. Integration of hydraulic models of the water supply and sanitary network into one coherent management system based on GIS is particularly important, owing to which a holistic assessment of the functioning of the water and sewage management system in the city is possible. [Cieżak et al., 2017, Czapczuk et al., 2017]. The decision support systems based on the spatial information system (GIS) associated with various specialized software, are becoming the standard of modern management of a water and sewage company. However, the research conducted by the entities offering commercial solutions in this area shows that only about $40 \%$ 
of companies in this industry use the systems of this type, while the vast majority are interested in their implementation or development in the near future. In addition, most of the GIS-based management systems used in practice are limited to an inventory of the existing network resources and integration of many databases into one coherent IT system. Only in a few cases the systems of this type contain the modules modeling the network operation under dynamic conditions, which results primarily from the additional implementation costs related to the construction of sufficiently reliable models of the water supply and / or sewerage network.

Long-term stagnation in the transfer of modern technologies and technical solutions has now led to an increased interest of municipal enterprises in the field of implementing the IT tools supporting water and sewage management [Kulbik, 2018]. This is mainly due to the need to reduce the operating costs, improve the operation of the existing networks, and increase the efficiency of enterprise management.

The dynamic network model is a highly efficient tool supporting observation and its operation, allowing for making justified decisions regarding the operation, modernization and expansion of the entire water supply and sewage system of a city or commune. The precision of the model's operation largely depends on the accuracy of the entered data contained in the digital geodetic sleepers. The data is entered with the selected software into the GIS data and for modeling. It can also be done in one integrated environment [Boulos Gao et al., 2009, Kulbik, 2018].

Conducting computer simulations of the water supply network is designed to help find a method and a way to improve the quality of the water supplied by the water supply network. Using dedicated software, one can model, among others the changes in water age throughout the distribution system. Fresh water flows into the network from tanks or a source. The age of the water in the pipes is a parameter that determines the freshness of the water and affects its quality. The model takes into account the time in which water stays in a given section from the moment it enters the intake and mixes it with the water already existing in the network [Kulbik, 2018].

Modeling and hydraulic simulations of the sewerage network under dynamic conditions using the available software will allow obtaining the information on the forecast parameters of the network in any conditions, giving the opportunity to better understand the complex set of factors determining the effectiveness of the entire system [Studziński, 2014].

Currently, comprehensive management systems are available on the market, dedicated to the enterprises from the water and sewage industry, built on the basis of GIS systems and containing the modules for computer modeling of water and sewerage networks. These are solutions of such companies as: Bentley Systems (USA), MIKE Powered by DHI (Denmark), Stanet (Germany). These companies have representative offices in Poland and deal with the implementation of comprehensive platforms for integrated enterprise management, also using mathematical modeling of the work of the water supply and sewage disposal network. However, these solutions require the purchase of expensive licenses and expensive service packages performed by external companies. The costs of such implementations often

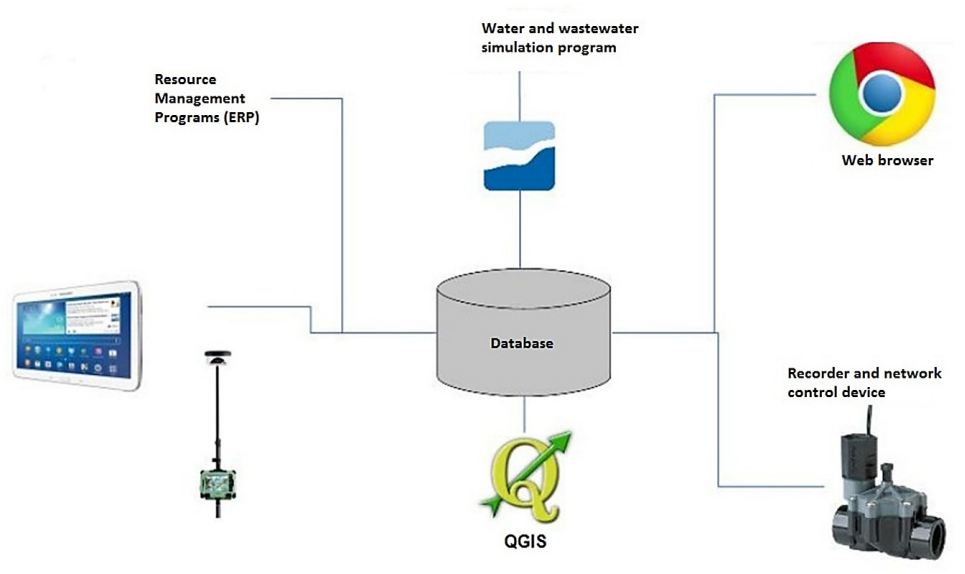

Fig. 1. Application schema used by the implemented system, centralized in the database [giswater.org] 


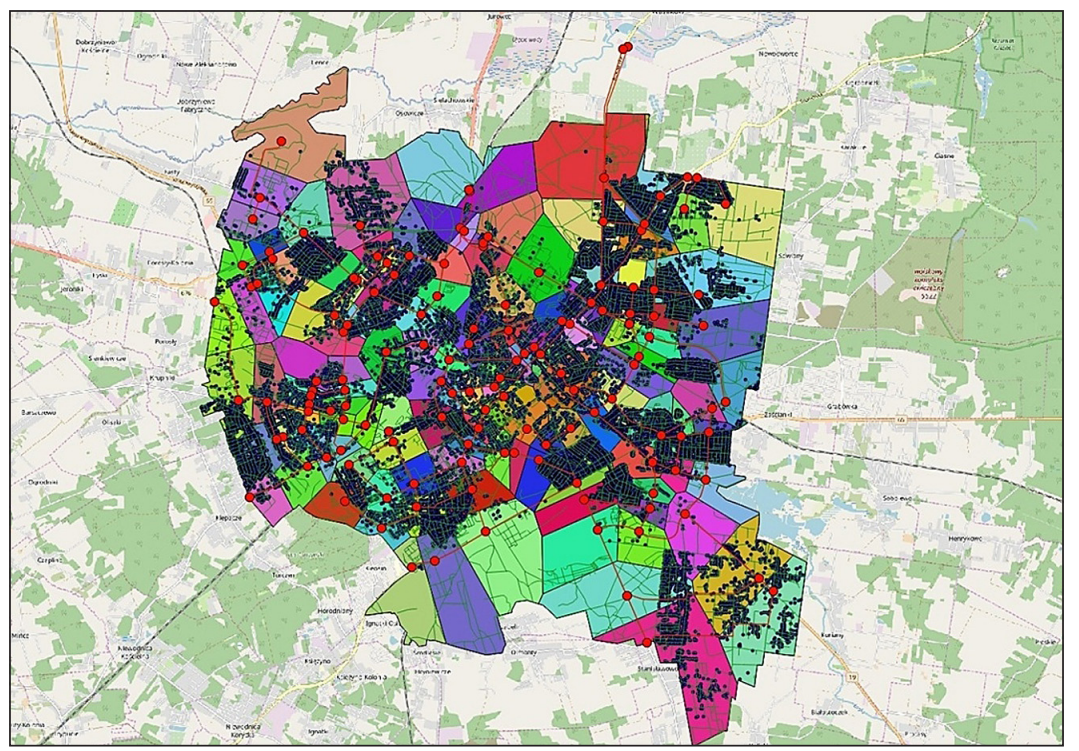

Fig. 2. The use of GIS to map the water distribution system (main conduits) in the city of Białystok. The figure shows the main nodes of the network along with the division into their water consumption areas developed using voronoi diagram [thanks to MSc. Monika Kolendo]

exceed the budgetary capabilities of small water supply companies. The reduction of costs associated with the purchase of licenses and support for implemented solutions can be achieved through the use of Open Source software and the use of the experience of the scientific and research staff. The freeware modeling and GIS software is successfully used for this purpose. These environments can be combined using the existing platforms or by building one's own software.

The most important tasks of GIS in the operation of water supply and sewage systems are:

- network inventory,

- centralizing information and data in one database that allows simplifying the control and verification of information and topological features of network objects,

- easy and quick access to data and their easy exchange inside the company,

- improving the process of removing failures,

- enabling current and continuous control of hydraulic and quality parameters related to the functioning of the network through registration,

- archiving and graphic representation of measurements collected via an industrial automation system,

- the ability to create simulations of network operation for the modernization and development needs through the use of analytical spatial models,

- significant improvement of customer service.
Contemporary geoinformation systems for the water and wastewater infrastructure are complex platforms integrated with tools for monitoring and mathematical modeling. They also work with other IT systems, such as: supervisory and information gathering systems - SCADA (Supervisory Control And Data Acquisition), work management systems - WMS (Work Management Systems) or archival documentation support systems - EDMS (Electronic Document Management Systems).

The entire enterprise IT system is usually built on a modular, integrated GIS platform. The selection of individual system elements and tools included in its composition should be preceded by a thorough analysis of profitability, i.e. determination of the ratio of potential benefits arising from the implementation of such a system to the expenditure incurred.

The payback period for the implementation of the GIS IT system is reduced as the size of the water supply and sewage system in use increases. Before starting modeling, it is necessary to decide on the choice of software and how to implement it - a company, an external institution, or your own human resources (training specialists to make and operate the model) [Gwozdziej-Mazur et al., 2018].

The network manager has the ability to quickly perform many simulations of any type, for example in terms of optimizing management methods, optimizing the maintenance and repair 
plan, and to determine the appropriate operating regimes [Trębicka, 2017].

Water supply network operators are increasingly aware of the need for constant supervision over the quality of water in the distribution system. As proven by numerous experiments, even if the water is treated in accordance with the applicable standards, there may be situations that after reaching the user, its parameters will deteriorate and it will not meet the requirements in terms of the taste, smell, color and content of active biological pollutants [Gwoździej-Mazur et al., 2018].

Water supply networks, especially in small and medium-sized municipalities, are often branched systems with small water divisions. In such networks, the problem of secondary water pollution often arises as a result of the water being in the pipes for too long, while the household and economic networks start sewage kneading processes. Such enterprises often lack an integrated water and wastewater management system based on digital sleepers and monitoring systems for selected parameters.

\section{RESULTS}

As a result of simulations carried out in the existing models, it was found that it is possible to reduce the percentage of average water age in the pipes. In the tested water supply networks in the 72 hour simulation, the water age fell by $4.82 \%$ compared to the existing state, while in the 240 hour simulation, the water age decreased by 10.72\% [Gwoździej-Mazur et al., 2018]. In real implementations, it is assumed to find a solution while maintaining the standards allowing for a higher percentage reduction of water age. However, this requires full implementation of the research system in the selected enterprise. The analysis of the speed distribution made on the existing state models of all tested water supply networks showed that in most pipes, its values are lower than the recommended level of $0.5 \mathrm{~m} / \mathrm{s}$. Insufficient water velocity in the pipes causes deposits to build up on the bottom of the pipelines and reduce the permeability of the conduit, which causes an increase in the water pressure and flow velocity in a given section. At some point, an increase in the flow velocity causes the accumulated sludge to be carried away and contaminate the water transported to the final consumer. At longer sections and low flow rates, there is also the phenomenon of water stagnation in the lines, which may result in the risk of secondary bacterial growth. Hence, the recommendations that the water speed should be in the range of $0.5-1.3 \mathrm{~m} / \mathrm{s}$.

The implementation of the integrated system should allow water to regulate the pressure

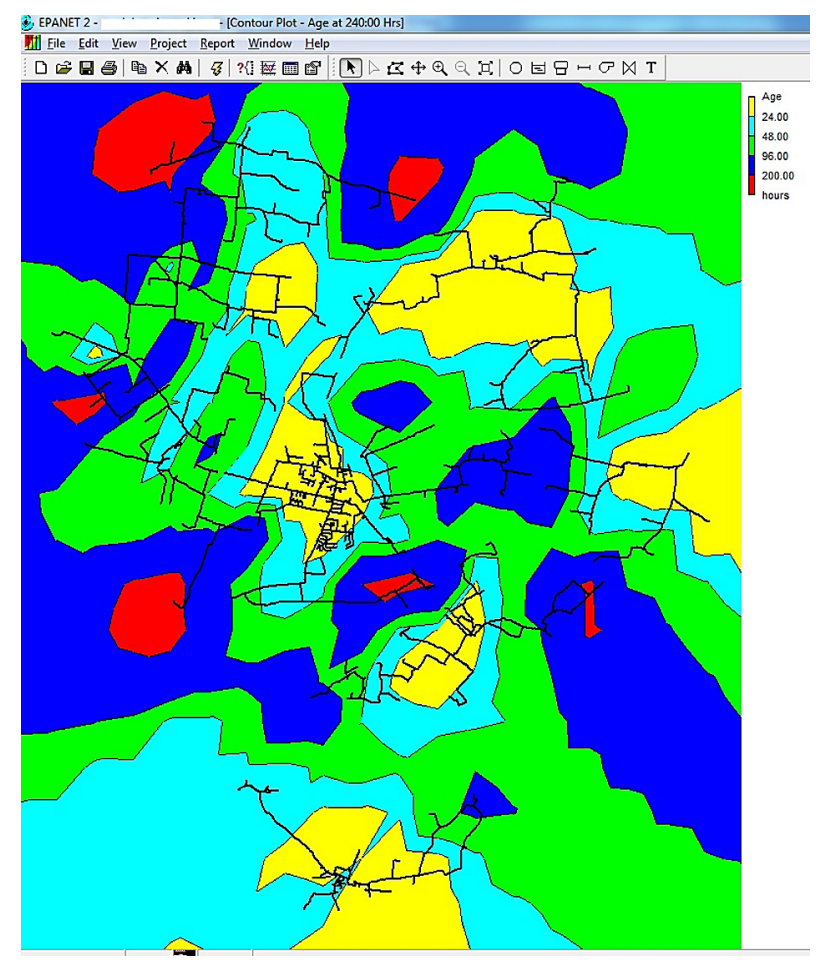

Fig. 3. Modeling the age of water in the water supply network in the selected commune $\mathrm{X}$ - the existing state 
in order to maintain its value at each point in the pressure range with an accuracy of $+/-10 \%$, reduce areas at speeds below $0.2 \mathrm{~m} / \mathrm{s}$ by at least $20 \%$ and reduce the average the age of water supplied in the areas with the longest water age by at least $20 \%$ and a reduction of water loss by $12 \%$. In sewerage networks, the implementation of the developed solutions will reduce the rainwater inflow to the wastewater treatment plant and reduce the parts of the network operating under pressure during rainy weather by at least $10 \%$.

Currently, a lot of water and sewerage networks are made in rural communes, and investors often do not have adequate knowledge about the possibilities and benefits of hydraulic modeling. Creating a sanitary sewage system model is more labor-intensive than a water supply network model for the same area. However, the workload is compensated by the fact that the model made and calibrated is an irreplaceable tool for assessing the hydraulic conditions. Modeling can be used already at the stage of conceptual solutions when creating functional and utility programs, and when performing construction projects, it can replace the traditional calculation methods in some cases. In analyzing existing, often leaky sewerage networks, an additional advantage is the possibility of employing a mathematical approach to the supply of accidental waters, both rainwater and groundwater. The share of these waters in the sanitary sewage system is often significant. The calibrated hydraulic model reveals the critical locations of the existing sewage system, facilitating making the investment decisions.

\section{CONCLUSIONS}

A functional solution increasing the quality of services in the water and sewage sector based on the results of hydrodynamic modeling in conjunction with the monitoring network and GIS database allows:

- in the water supply network: improving the water quality by choosing the optimal operating parameters that reduce age and increase the average water flow rate in the pipes;

- in the sewerage network: reducing the amount of infiltration and accidental waters as well as minimizing the risk of odor nuisance in the sewage network

- savings resulting from abandoning improper investments - checking their validity by simulations in the program. Planning "outages" on networks involving rinsing, renovations or investments in a way that does not compromise

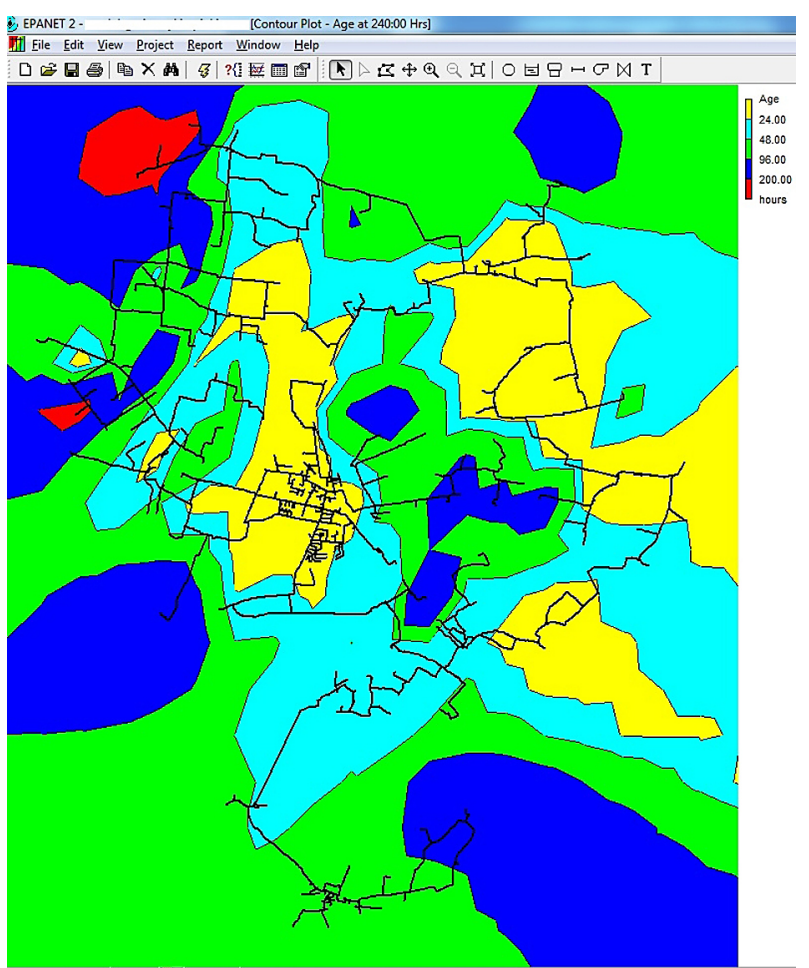

Fig. 4. Simulation results of changes in pipe connections to reduce the age of water in the model of the selected commune $\mathrm{X}$ 


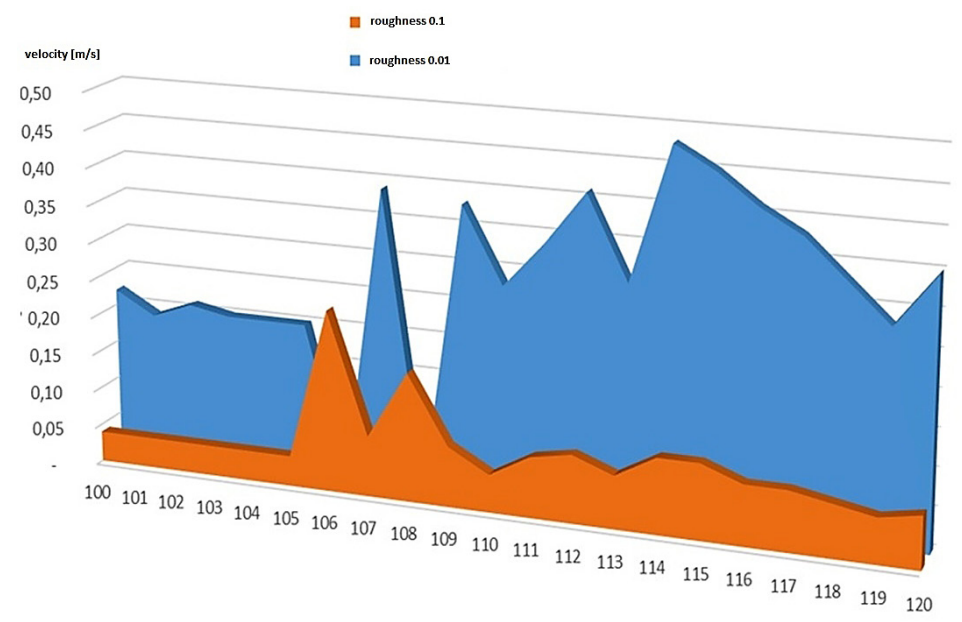

Fig. 5. Example of computer modeling of flow velocity in the sewerage network of the city of Supraśl in the SWMM program. The analysis of the results of modeling the impact of changes in pipe roughness on wastewater flow velocity (Y axis - flow velocity, m/s, X axis - conduit number) [Rewiński, 2018]

the standards of water supply or sewage disposal to residents during their lifetime

- reducing the operating costs and network losses by reducing the source efficiency during the smallest partitions

- reduction of the operating costs by controlling the operation of the pumping station (proven simulations in the model) in such a way as to reduce the energy consumption, while maintaining the standards of water supply and sewage disposal to residents.

- gives full knowledge in real time about the parameters, i.e. the quantity and quality of water supplied anywhere in the water supply network or sewage flows in the domestic and economic sewage system, as well as additional knowledge on the interaction of water supply and sewerage systems under dynamic conditions.

\section{Acknowledgements}

The research was carried out as part of the work No. WZ/WBiIŚ/02/2019 and financed from funds for the Ministry of Science and Higher Education.

\section{REFERENCES}

1. Boulos P.F., Lansey K.E., Kamey B.W. 2009. Comprehensive Water Distribution Systems Analysis Handbook for Engineers and Planners. MWH Soft, Pasadena.
2. Cieżak W., Cieżak J, Kotowski A., Kaźmierczak B, Kutyłowska M. D., Nowakowska M. W., Wartalska K. E., Wójtowicz P. 2017, (in Polish) Modelowanie matematyczne systemów wodociągowych i kanalizacyjnych ze względu na bezpieczeństwo działania. Raporty Wydziału Inżynierii Środowiska Politechniki Wrocławskiej, Ser. SPR nr 22, p. 24.

3. Czapczuk A., Dawidowicz J., Piekarski J. 2017, Application of Multilayer Perceptron for the Calculation of Pressure Losses in Water Supply Lines, Rocznik Ochrona Środowiska, 19, 540-556

4. Gwoździej-Mazur J., Świętochowski K., Kaźmierczak B. 2018, Analysis of water losses and failure frequency in an urban-rural water supply system, Ekonomia i Środowisko, 2, 76-86.

5. Gwozdziej-Mazur J., Świętochowski K. 2018, Analysis of the water meter management of the urban-rural water supply system, E3S Web of Conferences, 44, p. 8.

6. Kulbik, M. 2018, (in Polish) Przykłady realizacji i interpretacji wyników sondażowych pomiarów terenowych w czynnych systemach wodociągowych, Polskie Zrzeszenie Inżynierów i Techników Sanitarnych Oddział Wielkopolski, 218-219.

7. Rewiński J. 2018, (in Polish) Komputerowe modelowanie kanalizacji dla wybranej miejscowości, Bialystok Technical University, Master's thesis, supervisor Kruszyński W., Białystok

8. Studziński J. 2014. Some algorithms supporting the water network management by use of simulation of network hydraulic model.W: Industrial Simulation ConferenceISC 2014, 11-13.06.2014, Hoegskolan, EUROSIS 2014, 33-37.

9. Trębicka A. 2017. (in Polish) Modelowanie systemu dystrybucji wody na przykładzie miasta Łapy. Inżynieria Ekologiczna, 18(6), 105-109. 